Original Contribution

\title{
INVESTIGATION ON ENERGY AND PROTEIN TRANSFORMATION ALONG THE TROPHIC CHAIN “FEED - JAPANESE QUAIL'S EGGS” USING THE SYSTEM “CLARCS OF TRANSFORMATION/DISTRIBUTION"
}

\author{
D. Penkov ${ }^{1 *}$, A. Genchev ${ }^{2}$ \\ ${ }^{1}$ Department of Animal Sciences, Agricultural University, Plovdiv, Bulgaria \\ ${ }^{2}$ Department of Poultry Breeding, Trakia University, Stara Zagora, Bulgaria
}

\begin{abstract}
An investigation of the energy and protein transformation along the trophic chain "feed - egg mélange" in 2 breeds of Japanese quails has been conducted. The system "Clarcs of energy distribution (CED) and Clarcs of (crude) protein transformation (CPT)" was developed. The following values were established: CED „feed - egg mélange“ - between from 0.1851 (Pharaoh) to 0.1885 (Manchurian golden); CPT „feed - egg mélange“- between from 0.1905 (Pharaoh) to 0.1932 (Manchurian golden).
\end{abstract}

Key words: Biotransformation, eggs, feed, Japanese quails

\section{INTRODUCTION}

Bioconversion of feed into human-edible products is expressed by the feed conversion ratio. In egg poultry farming it is specified as "feed intake per 1 egg or $1 \mathrm{~kg}$ of egg mass" (1-8).

On the other hand, there is a need for a proper and standardized determination and comparison of the transformation of energy and different nutrients in the feeding diet into human-edible products both for breeding purposes and for the improvement of feeding and breeding technologies.

Following that issue and continuing the ideas set forth in our previous publication (9), we set the aim of developing a methodology and supporting it with examples of scientific and economic investigations to introduce objective criteria for the distribution of the metabolizable energy and crude protein in mixed feed to their content in 1 $\mathrm{kg}$ of the edible egg mass - egg yolk/egg white/egg mélange from Japanese quail layers. Through this approach, these criteria could be converted from biological in technology and selection indices and can support the development and improvement of breeding and production technologies.

\footnotetext{
*Correspondence to: Dimo Penkov, Department of Animal Sciences, Agricultural University, 4000Plovdiv, Bulgaria, E mail: dimopenkov@gmail.com
}

\section{MATERIAL AND METHODS}

The study has been carried out to evaluate the egg-laying characteristics of 2 breeds of Japanese quail - Pharaoh and Manchurian golden for one egg-laying season. Quails were fed with one phase combine feed for the whole laying period, same for both groups (Table 1). The egg-laying cycle lasting about 178 days - from 35 until 213 days of age.

Egg production control started from the time of laying the first egg and continued until the end of the $7^{\text {th }}$ productive month. Egg production was carried out by daily recording the number of eggs laid in each group of layers and differentiating them into standard and culled eggs.

Throughout the period, the number of dead and culled quails was monitored every day, the sum of the feeding days was calculated, and hence the egg productivity of a Hen-Day Egg Production.

Control of the feed consumed was carried out twice in each productive month within 3 consecutive days. The average of the three days for each group was taken as the average daily feed consumption per bird.

The egg weight of the two breeds was measured individually using Chirana 02 scales with an accuracy of $0.1 \mathrm{~g}$. The mean of the two 
control weights was taken as the average egg weight for the breed in the respective productive month. The feed consumption values, the number of eggs laid and the egg weight were used as the basis for the calculation of feed consumption per $1 \mathrm{egg}$ and $1 \mathrm{~kg}$ of egg mass (10).

The following formulas were used for calculating the Feed conversion ratio (FCR), Clarc of energy distribution (CED) and Clarc of (crude) protein transformation (CPT):
PENKOV D., et al. Feed conversion ratio $(\mathrm{FCR}, \mathrm{kg} / \mathrm{kg})=$ kilograms of egg mass obtained from 1 layer $/ \mathrm{kg}$ feed consumed by 1 layer for the whole laying period [1] CED = MJ gross energy (GE) obtained from 1 layer (given by the dry mass of the egg white/yolk) / MJ metabolizable energy (ME) consumed for the whole egg-laying period [2] $\mathrm{CPT}=\mathrm{kg}$ crude protein $(\mathrm{CP})$ obtained from 1 layer (given by the dry mass of the egg white/yolk) / $\mathrm{kg} \mathrm{CP}$ consumed for the whole egglaying period [3]

Table 1. Composition and nutrients in complete compound feed for Japanese quails - layers.

\begin{tabular}{lc}
\hline Compounds & $\%$ \\
\hline Maize & 29.42 \\
Wheat & 29.42 \\
Sunflower meal, 37\% & 15 \\
Soybean meal, 44\% & 17.77 \\
Potassium phosphate & 1.65 \\
Chalk & 5.6 \\
L- lysine & 0.18 \\
DL - methionine & 0.06 \\
Vit. - min. premix - 4PS® & 0.5 \\
Salt & 0.3 \\
& \\
Metabolizable energy (ME), MJ & 10.8 \\
Crude protein (CP), \% & 19.1 \\
Crude fiber, \% & 5.7 \\
Ca, \% & 2.5 \\
Available P, \% & 0.4 \\
Lysine, \% & 0.95 \\
Methionine, \% & 0.38 \\
Methionine + cysteine, \% & 0.74 \\
\hline
\end{tabular}

All data were analysed with Statistica 13.0 software (Statistica for Windows; Stat-Soft, 2015). Mean (x) and standard error of mean (SEM) values were calculated for each breed.

\section{RESULTS AND DISCUSSION}

Data about the total feed consumption, metabolizable energy and crude protein are shown in Table 2.

Layers of Pharaoh breed consumed $70.6 \mathrm{~g}$ more feed, significantly more metabolizable energy and crude protein, respectively, which is logical, rendering an account of the difference in live weight and production type between the two breeds.

The established in our study average daily feed consumption ratio (41.4 - $41.6 \mathrm{~g} /$ day/quail), shows significant differences (14-18\%) compared to the quails from medium heavy type $(11,12)$ and $23.6-33.6 \%$, compared to the races that are lighter in body weight (4). The higher live weight and lower laying intensity of Pharaoh breed, were the major reasons for the difference between the two studied breeds in terms of feed consumption for the production of 1 standard egg (53.1 $\mathrm{g}$ versus $55.3 \mathrm{~g}$ in Pharaoh breed. However, the higher egg weight of 5 to $6.3 \%$ in Pharaoh breed is the reason for eliminating the difference by using the more precise and more objective characteristic - feed conversion per $1 \mathrm{~kg}$ of egg mass. The average conversion of feed for the productive cycle in the two breeds was practically the same $-4.06 \mathrm{~kg} / \mathrm{kg}$ of egg mass in Manchurian golden and $4.05 \mathrm{~kg}$ in Pharaoh breed, the variation being between 3.6 and 4.5 $\mathrm{kg} / \mathrm{kg}$ of egg mass depending on the stage of the production cycle. 
PENKOV D., et al.

Table 2. Feed consumption, metabolizable energy $(\mathrm{ME})$ and crude protein $(\mathrm{CP})$ from Hen-Day Egg Production for the whole egg-laying period.

\begin{tabular}{lcccc}
\hline Characteristics & \multicolumn{2}{c}{ Manchurian golden } & \multicolumn{2}{c}{ Pharaoh } \\
& X & SEM & x & SEM \\
\hline Average body weight, g & $259.7^{* * *}$ & 1.80 & $326.6^{* * *}$ & 3.16 \\
Feed consumption for the period - g/layer & $7338.10^{*}$ & 13.00 & $7408.72^{*}$ & 10.39 \\
Consumed ME for the period - MJ/layer & $79.25^{*}$ & 0.14 & $80.01^{*}$ & 0.11 \\
Consumed CP for the period - g/layer & $1401.58^{*}$ & 2.48 & $1415.07^{*}$ & 1.98 \\
Laying period - mean (days) & \multicolumn{2}{c}{177.5} & \multicolumn{2}{c}{177.6} \\
Average egg number/bird & 164.61 & 2.54 & 155.92 & 3.57 \\
\hline
\end{tabular}

Statistical significance, ${ }^{*} \mathrm{P} \leq 0.05 ; * * * \mathrm{P} \leq 0.001$.

The relatively uniform length of the egg-laying period was due both to the fact that the birds of the two breeds mature at a similar age and to the practice of culling them at the same age (10). Layers of Pharaoh breed lay significantly heavier eggs, but the Manchurian golden quails largely compensate for the amount of eggs produced because of their higher laying intensity, the differences between the two breeds at the end of the laying season being insignificant (Table 3).

Manchurian golden quails produce a higher percentage of protein in the whole egg, the differences being statistically significant $(\mathrm{P}<0.05)$, whereas the layers of Pharaoh breed tend to produce heavier as an absolute weight and more regular egg yolks (Table 3). Nevertheless, the yolk of Manchurian golden quails is also higher in percentage of the whole egg.

Quantitative calculations show that Manchurian golden quails produced significantly more protein and yolk as a total weight compared to Pharaoh breed. When comparing the gross energy produced, we did not find significant differences, while the differences in crude protein were low, but statistically significant, and they were in favor of Manchurian golden quails $(\mathrm{P}<0.05)$.

In general, the biotransformation of both the metabolizable energy and crude protein from feed to energy and protein in the edible parts of the egg were higher than those established for breast and thigh muscles (9). Data show that the distribution of the metabolizable energy to energy in the mélange was more than $18 \%$ in total, while in Manchurian golden quail it was about $0.5 \%$ more efficient.

Biotransformation of feed protein to the edible parts of the egg had the same tendency in the breeds, the total transformation exceeding $19 \%$.

Table 3. Characteristics of egg productivity in Japanese quails $(G E=$ gross energy, $C P=$ crude protein $)$.

\begin{tabular}{|c|c|c|c|c|}
\hline \multirow[t]{2}{*}{ Characteristics } & \multicolumn{2}{|c|}{ Manchurian golden } & \multicolumn{2}{|c|}{ Pharaoh } \\
\hline & $\mathrm{X}$ & SEM & $\mathrm{x}$ & SEM \\
\hline Egg weight (1 egg), g & $12.98^{*}$ & 0.13 & $13.74 *$ & 0.15 \\
\hline Albumen weight (1 egg), g & 8.08 & 0.053 & 7.93 & 0.051 \\
\hline Yolk weight (1 egg), g & 4.03 & 0.29 & 4.13 & 0.031 \\
\hline$\%$ of egg albumen & $62.25^{*}$ & 0.09 & $57.71 *$ & 0.20 \\
\hline$\%$ of egg yolk & 31.05 & 0.21 & 30.06 & 0.09 \\
\hline $\begin{array}{l}\text { Produced egg weight from } 1 \text { layer for the whole } \\
\text { laying period, g }\end{array}$ & 2156.31 & 33.23 & 2183.13 & 23.56 \\
\hline $\begin{array}{l}\text { Produced egg albumen from } 1 \text { layer for the } \\
\text { whole laying period, } g\end{array}$ & $1342.30 *$ & 16.66 & $1259.99 *$ & 11.83 \\
\hline $\begin{array}{l}\text { Produced egg yolk from } 1 \text { layer for the whole } \\
\text { laying period, } g\end{array}$ & $669.49 *$ & 16.72 & $656.21 *$ & 11.82 \\
\hline $\begin{array}{l}\text { Produced GE from egg albumen from } 1 \text { layer for } \\
\text { the whole laying period, MJ }\end{array}$ & 4.23 & 0.01 & 4.16 & 0.03 \\
\hline $\begin{array}{l}\text { Produced CP from egg albumen from } 1 \text { layer for } \\
\text { the whole laying period, } g\end{array}$ & $170.92 *$ & 0.16 & $168.12 *$ & 0.13 \\
\hline $\begin{array}{l}\text { Produced GE from egg yolk from } 1 \text { layer for the } \\
\text { whole laying period, MJ }\end{array}$ & 10.71 & 0.01 & 10.49 & 0.01 \\
\hline $\begin{array}{l}\text { Produced CP from egg yolk from } 1 \text { layer for the } \\
\text { whole laying period, } g\end{array}$ & $103.50^{*}$ & 0.39 & $101.45^{*}$ & 0.28 \\
\hline
\end{tabular}


Table 4. Clarcs of energy and crude protein distribution/transformation in Japanese quails.

\begin{tabular}{ccc}
\hline & Clarc of energy distribution & \\
\hline To the albumen & 0.0534 & 0.0520 \\
& $(5.34 \%)$ & $(5.20 \%)$ \\
To the egg yolk & 0.1351 & 0.1331 \\
& $(13.51 \%)$ & $(13.31 \%)$ \\
\multirow{2}{*}{ Total (to the mélange) } & 0.1885 & 0.1831 \\
& $(18.85 \%)$ & $(18.51 \%)$ \\
\hline & Clarc of protein transformation \\
\hline To the albumen & 0.1175 & 0.1188 \\
& $(11.75 \%)$ & $(11.88 \%)$ \\
To the egg yolk & 0.0757 & 0.0717 \\
& $(7.57 \%)$ & $(7.17 \%)$ \\
Total (to the mélange) & 0.1932 & 0.1905 \\
& $(19.32 \%)$ & $(19.05 \%)$ \\
\hline
\end{tabular}

Data obtained about Clarcs of distribution/biotransformation of energy and protein from the primary trophic level (feed) to secondary trophic level (edible products) from quail layers (Table 4) are considered a good basis for further research and comparison to the results of other authors in order to enrich the information.

\section{CONCLUSION}

Despite the lower egg weight, the lower total egg white production per layer for the laying season, Manchurian golden quails produced significantly more egg yolk and more crude protein from egg white and yolk than the layers of Pharaoh breed. The same tendency was established in gross energy production, although the differences were statistically insignificant.

The Clarc of energy distribution from feed to egg mélange was, as follows:

-to egg white - from 0.0520 (Pharaoh) to 0.0534

(Manchurian golden)

-to egg yolk - from 0.1331 (Pharaoh) to 0.1351

(Manchurian golden)

-total (to the mélange) - from 0.1851 (Pharaoh) to 0.1885 (Manchurian golden).

The Clarc of crude protein transformation from feed to egg mélange was, as follows:

-to egg white - from 0.1175 (Manchurian golden) to 0.1188 (Pharaoh)

-to egg yolk - from 0.0717 (Pharaoh) to 0.0757 (Manchurian golden)

-total (to the mélange) - from 0.1905 (Pharaoh) to 0.1932 (Manchurian golden).

\section{REFERENCES}

1. Fairfull, R. W. and Chambers, J. R., Breeding for feed efficiency: Poultry. Canadian Journal of Animal Science, 64(3): 513, 1984.

2. Nikolova, M. and Gerzilov, V., Study of growth characteristics of little geese of Benkovska byala and Landenska breeds and their F1 crossings. Proceedings of Jubilee scientific session "Sustainable Agriculture in the transition to a market economy", Academic Publishing House of HIA Plovdiv, vol. IV, book 1, 291-294, 1995.

3. Emmerson, D. A., Commercial approaches to genetic selection for growth and feed conversion in domestic poultry. Poultry Science, 76(8): 1121-1125, 1997.

4. Tarasewicz, Z., Szczerbińska, D., Ligocki, M., Wiercińska, M., Majewska, D. and Romaniszyn, K., The effect of differentiated dietary protein level on the performance of breeder quails. Animal Science Papers and Reports, 24(3):207-216, 2006.

5. Kadam, M. M., Mandal, A. B., Elangovan, A. V., and Kaur, S., Response of laying Japanese quail to dietary calcium levels at two levels of energy. The Journal of Poultry Science, 43:351-356, 2006.

6. Nahashon, S., Adefope, N., Amenyenu, A. and Wright, D., Laying performance of pearl gray Guinea fowl hens as affected by caging density. Poultry Science 85(9):16821689, 2006.

7. Grigorova, S., Surdjiiska, S. and Gjorgovska, N., Effects of the use of highprotein rapeseed feed on laying productivity and egg quality in Japanese quails. Scientific Papers, Series D. Animal Science, Vol LX, București, Romania, 2017.

8. Boncheva, V., Petrov, P. and Gerzilov, V., Egg production from dual purpose hen genotypes reared in a free range system. Bulgarian Journal of Agricultural Science, 24(1): 119-125, 2018.

9. Penkov, D. and Genchev, A., Methods for introduction of objective criteria for bioconversion of energy and nutrients along 
the feed - animal products chain in meettype poultry farming. Journal of Central European Agriculture, 19 (2): 270-277, 2018.

10. Genchev, A., Productive characteristic of Japanese quails (Coturnix coturnix japonica) from the breeds Pharaoh and Manchurian Golden. D. Sc. Dissertation, Trakia University, Bulgaria, 2014.

11. Dere, S., Balevi, T., Inal, S., Kurtoglu V. and Yilmaz, A., The effect of oil refinery
PENKOV D., et al. by-products on reproductive and rearing performance in Japanese quail. VeterinerBilimleri-Dergisi, 16(1): 129-133, 2000.

12. Alagawany, M. and Attia, A., Effects of feeding sugar beet pulp and Avizyme supplementation on performance, egg quality, nutrient digestion and nitrogen balance of laying Japanese quail. Avian Biology Research, 8(2):79-88, 2015. 